Volume 1 Nomor 2 Edisi Desember 2013
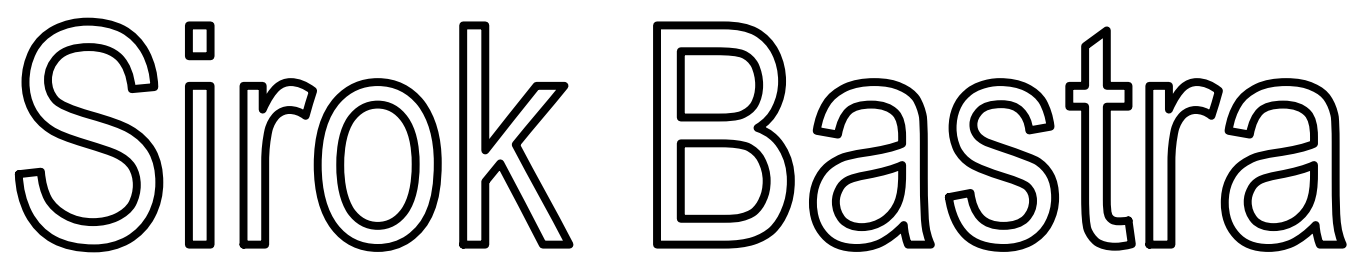

J URNAL ILMIAH KEBAHASAAN DAN KESASTRAAN

\begin{tabular}{|c|c|c|c|c|c|}
\hline $\begin{array}{c}\text { Sirok Bastra } \\
\text { Jurnal Kebahasaan dan } \\
\text { Kesastraan }\end{array}$ & Volume 1 & Nomor 2 & $\begin{array}{c}\text { Hlm. } \\
123-249\end{array}$ & $\begin{array}{c}\text { Pangkalpinang, } \\
\text { Desember } \\
2013\end{array}$ & $\begin{array}{c}\text { ISSN } \\
2354-7200\end{array}$ \\
\hline
\end{tabular}

KANTOR BAHASA KEPULAUAN BANGKA BELITUNG 

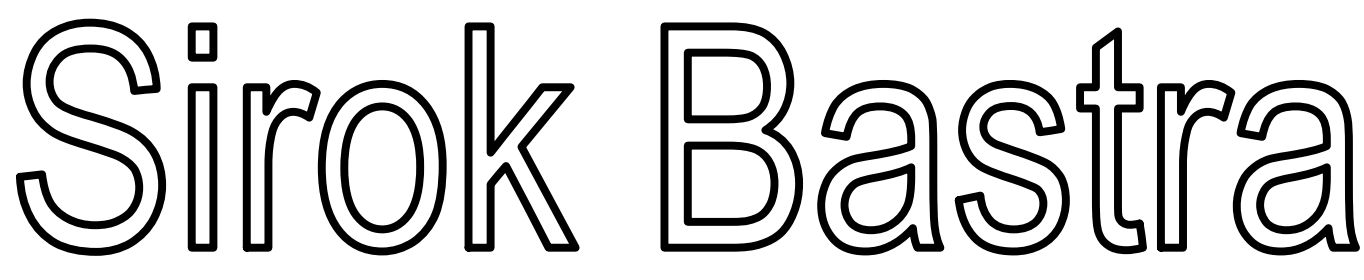

\section{J URNAL ILMIAH KEBAHASAAN DAN KESASTRAAN}

Jurnal ini merupakan wadah informasi mengenai kebahasan, kesastraan, dan pengajarannya yang memuat hasil penelitian, studi kepustakaan, dan tulisan ilmiah bidang kebahasan, kesastraan, dan pengajarannya. Jurnal ini terbit dua kali setahun, yakni Juni dan Desember, serta terbit sejak Juni 2013.

\section{Penanggung Jawab}

Kepala Kantor Bahasa Provinsi Bangka Belitung

Drs. Umar Solikhan, M.Hum.

\section{Mitra Bestari}

Prof. Dr. Agus Nuryatin, M.Hum. (Bidang Bahasa dan Pengajarannya)

Prof. Amrin Saragih, Ph.D., M.A. (Bidang Sastra dan Pengajarannya)

Dr. Felicia Nuradi Utorodewo, M.Hum. (Bidang Bahasa dan Pengajarannya)

Dr. Pujiharto, M.Hum. (Bidang Sastra dan Pengajarannya)

\section{Pemimpin Redaksi}

Rahmat Muhidin, S.S.

\section{Penyunting}

Prima Hariyanto, S.Hum.

\section{Perancang Sampul}

Feri Pristiawan, S.S.

\section{Kesekretariatan}

Khaliffitriansyah, S.Pd. Dea Letriana Cesaria, S.Hum.

Lia Aprilina, S.Pd.

Andrian Priyatno, A.Md.

Elzam

\section{Alamat Redaksi dan Penerbit}

Kantor Bahasa Provinsi Bangka Belitung

Ruko Permata 7, Jalan Solihin G.P. Km 4, Pangkalpinang, Kep. Bangka Belitung

Telp./Faks.: 0717-438455, Pos-el: sirokbastra@gmail.com

Pemuatan suatu tulisan dalam jurnal ini tidak berarti redaksi menyetujui isi tulisan tersebut. Isi tulisan menjadi tanggung jawab penulis. Tulisan telah ditinjau oleh mitra bestari. Setiap karangan dalam jurnal ini dapat diperbanyak setelah mendapat izin tertulis dari penulis, redaksi, dan penerbit. 


\section{KATA PENGANTAR}

Puji syukur ke hadirat Pemilik dan Pencipta semesta ini yang memiliki kuasa atas diri-Nya sendiri. Dialah Tuhan Yang Maha Esa yang telah memberikan rahmat dan hidayah-Nya sehingga Volume 1 Nomor 2 Jurnal Sirok Bastra dapat terbit tepat pada waktunya.

Pada nomor kedua ini, dimuat sebelas tulisan, yakni enam tulisan kebahasaan, empat kesastraan, dan satu pengajaran sastra. Dari segi bahasa, sebagian besar tulisan disajikan dalam bahasa Indonesia, hanya dua tulisan yang disajikan dalam bahasa Inggris. Kami mengucapkan terima kasih kepada para penulis yang telah bersedia menerbitkan karya mereka pada edisi ini. Para penulis merupakan para peneliti, pakar, dosen, dan mahasiswa dari berbagai perguruan tinggi dan instansi. Terima kasih juga kami sampaikan kepada para mitra bestari kami yang telah memberi ulasan terhadap tulisan-tulisan yang masuk ke redaksi.

Demi memenuhi keberagaman isi dan penulis, Sirok Bastra membuka kesempatan bagi para peneliti dan penulis menyampaikan hasil penelitian dan pemikiran mutakhir dalam bidang kebahasaan, kesastraan, dan pengajarannya.

Pangkalpinang, Desember 2013

Tim Redaksi 


\section{UCAPAN TERIMA KASIH UNTUK MITRA BESTARI}

Redaksi Sirok Bastra mengucapkan terima kasih kepada para mitra bestari yang telah meninjau, menimbang, dan mengulas makalah-makalah yang diterbitkan dalam Sirok Bastra Volume 1 Nomor 2, edisi Desember 2013, yakni

Prof. Dr. Agus Nuryatin, M.Hum.

Bidang Sastra dan Pengajarannya

Universitas Negeri Semarang

Semarang, Jawa Tengah

Prof. Amrin Saragih, Ph.D., M.A.

Bidang Bahasa dan Pengajarannya

Universitas Negeri Medan

Medan, Sumatra Utara

Dr. Felicia Nuradi Utorodewo, M.Hum.

Bidang Bahasa dan Pengajarannya

Universitas Indonesia

Depok, Jawa Barat

\section{Dr. Pujiharto, M.Hum.}

Bidang Sastra dan Pengajarannya

Universitas Gadjah Mada

Yogyakarta, Daerah Istimewa Yogyakarta 


\section{DAFTAR ISI}

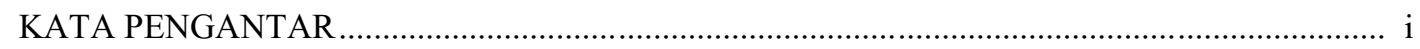

UCAPAN TERIMA KASIH UNTUK MITRA BESTARI .................................................... ii

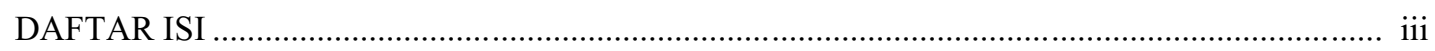

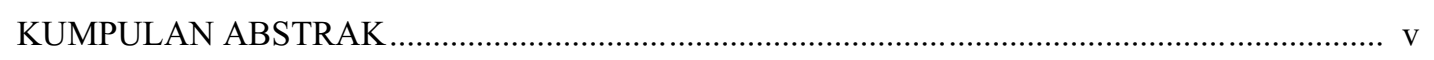

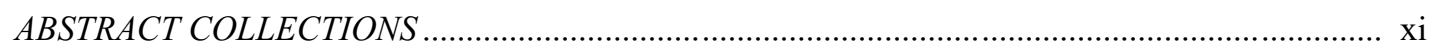

BAHASA INDONESIA DALAM INFORMASI DAN IKLAN DI RUANG PUBLIK KOTA PANGKALPINANG

(Indonesian in Information and Advertising in Public Space Pangkalpinang)

Umar Solikhan $123-129$

PERBEDAAN MAKNA NOMINA BERAFIKS $P E-, P E R-, P E--A N$, DAN $P E R--A N$ DALAM NASKAH HIKAYAT BAYAN BUDIMAN, HIKAYAT MUHAMMAD HANAFIYYAH, DAN HIKAYAT RAJA PASAI

(Affixed Noun Meaning Differences of pe-, per-, pe--an, and per--an in The Hikayat Bayan Budiman, Hikayat Muhammad Hanafiyyah, and Hikayat Raja Pasai Manuscripts)

Rindias H. Fatmasari $131-147$

WACANA RUBRIK INTIMATE DI MAJALAH DIGITAL INTERAKTIF MALE

(Intimate Rubric in Male Digital Interactive Magazine Discourse)

Prima Hariyanto $149-160$

AN ACOUSTICAL CONTRASTIVE ANALYSIS OF SUNDANESE CENTRAL VOWELS (Analisis Konstrastif Akustik Vokal Pusat Bahasa Sunda)

Yusup Irawan. $161-175$

KATA SUDAH SEBAGAI PENANDA ASPEK DENGAN AWALAN TER-

The Word of Sudah as An Aspect with Prefix Ter-

Dea Letriana Cesaria $177-182$

PERUBAHAN DAN PERGESERAN MAKNA DALAM KATA-KATA BERDERIVASI NOMINA KE VERBA YANG MENGANDUNG AFIKS $M E(N)-, M E(N)-K A N$, DAN $M E(N)-I$ PADA SURAT KABAR HARIAN KOMPAS

(Change and Shift of Meaning in The Derivated Words Nomine to Verb That Contain Affixes $m e(N)-$, me(N)-kan, dan me(N)- $i$ in The Kompas The Daily Newspaper)

Teodora Nirmala Fau $183-193$

MENCIPTA-KREATIF NASKAH DRAMA DENGAN STRATEGI MENULIS TERBIMBING (Creative Writing of Playscript eith Guided Writing Strategy)

Sony Sukmawan. $195-205$ 
PENGARUH KONSEP HAGABEON, HAMORAON, DAN HASANGAPON TERHADAP

KETIDAKSETARAAN GENDER DALAM AMANG PARSINUAN

(The Influence of Hagabeon, Hamoraon, and Hasangapon Concept for Gender Inequality in Amang Parsinuan)

Fransiska Simangunsong $207-220$

PERSPEKTIF PENGARANG MENGENAI RELASI ANTARA MANUSIA DAN

LINGKUNGAN HIDUP DALAM NOVEL PARTIKEL KARYA DEWI LESTARI: SEBUAH KAJIAN EKOKRITISISME

(Author's Perspective on The Relationship Between Humans and The Environment in The Novel Partikel Written by Dewi Lestari: an Ecocriticism Studies)

Alfi Yusrina Ramadhani $221-229$

FENOMENA HUKUM ADAT BALI TERHADAP BAYI KEMBAR BUNCING DALAM

NOVEL INCEST KARYA I WAYAN ARTIKA

Bali Custom Law Phenomenon of Kembar Buncing Infant in I Wayan Artika Novel Incest Annisa Aprinandri Irwin dan Khansa Khairunnisa $231-241$

RELIGIOUS AND MORAL VALUES IN MADURA FOLKTALES

Religiositas dan Nilai Moral dalam Cerita-Cerita Rakyat Madura

Imron Wakhid Harits. $243-249$ 


\title{
RELIGIOUS AND MORAL VALUES IN MADURA FOLKTALES
}

\section{Religiositas dan Nilai Moral dalam Cerita-Cerita Rakyat Madura}

\author{
Imron Wakhid Harits
}

Universitas Trunojoyo Madura

Jalan Raya Telang PO BOX 02 Kamal, Bangkalan, Madura

e-mail: imronwakhidharits@gmail.com

(diterima 8 Juli 2013, disetujui 30 September 2013, revisi terakhir 24 Oktober 2013)

\begin{abstract}
Madura has a lot of Folktales as the reflection of its values in its social life. As the cultural identity, most of Madura folktales are the mirror of social values and characteristics of Madura society. Thus, the Madura folktales contain the moral and religious values as the most important element for Madura society. The aim of this paper is to identify and to investigate five Madura folktales, these are: The Origin of Madura, Bangsadcara and Ragapadme, The Origin of Tajungan, Aer Mata Ebu, and Aryo Menak. These five folktales are chosen because they are the most popular Madura folktales among others. While, the aspects of moral and religious values are the most dominant elements that can be found in these five Madura folktales. Such two aspects are the local genious that can be bequeathed from one generation to the next generation. The aspect of moral will have the close relation with the appreciation and respecting to the parents and teacher on the other hand, the aspect of religious values are related with sufism and another Islamic values. Both of two aspects are used as the fundamental of social construction in Madura. Therefore the religious and moral aspects sourced in Madura Folktales must be explored to look for the identity as Madurese.
\end{abstract}

Keywords: Madura folktales, moral values, religious values

\begin{abstract}
Abstrak
Madura memiliki banyak cerita rakyat yang merupakan cerminan nilai - nilai kehidupan sosialnya. Sebagai identitas budaya, kebanyakan cerita rakyat Madura merupakan cerminan nilai - nilai sosial dan sebagai karakteristik masyarakat Madura. Dengan demikian, cerita - cerita rakyat Madura berisi nilai - nilai moral dan religius sebagai pilar utama dalam masyarakat Madura. Tujuan dari makalah ini adalah mengidentifikasi dan meneliti secara mendalam lima cerita rakyat Madura, yaitu: Asal mula Pulau Madura, Bangsadcara dan Ragapadme, Asal mula desa Tajungan, Aer Mata Ebu, dan Aryo Menak. Kelima cerita rakyat ini dipilih karena cerita - cerita tersebut sangat populer diantara yang lain. Sedangkan dalam cerita - cerita tersebut, aspek moral dan religius merupakan unsur yang sangat dominan dalam lima cerita rakyat tersebut. Dua aspek tersebut merupakan kearifan lokal yang bisa diwariskan dari satu generasi ke generasi berikutnya. Aspek moral disatu sisi memiliki hubungan yang erat dengan penghormatan dan penghargaan kepada orang tua dan guru, sedangkan aspek religius berkaitan dengan nilai - nilai sufi dan ajaran Islam lainnya. Kedua aspek tersebut digunakan sebagai dasar dalam konstruksi masyarakat Madura. Oleh Karena itu nilai - nilai agama dan juga moral yang bersumber dari cerita - cerita rakyat harus digali dan dipertahankan untuk terus mencari identitas sebagai orang Madura.
\end{abstract}

Kata kunci: cerita rakyat Madura, nilai - nilai moral, nilai-nilai keagamaan

\section{INTRODUCTION}

\subsection{Background of Study}

...Madura, I am your blood (Zawawi Imron)...

Being folktales are originated from the local genious, consequently they will reflect the characteristics of one traditional culture and the construction of the social life from the native society where these folktales are invented and developed. Folktales are used as the vehicle of didacticism, they can deliver and convey the values of one society, like social, historical, religious and moral values. They are the effective instruments to keep and maintain the 
tradition from one generation to the next generation. Because mostly folktales are the oral tradition, so that the parents can tell about these stories to their children before sleeping or in other leisure time. Thus, the future generation can be understood the root of tradition as the product of the local genious due to its unique that make it differ from other society. Folktales as the great heritage of one culture should be conveyed to defend the characteristics of the society.

Oral literature such as folktale usually have the simple themes. In line with this notion, the important things in the study of folktale is the use of folktales as media to convey the cultural heritage and moral message to the next generation of one society. Thus, the folktales mostly tell about moral teachings which are sourced from their own local genious or local wisdom and according to their cultural values as the reflection of their way of life. Based on Lyncn Brown and Tomlison (1999) there are three general themes in folktales, merely: good versus evil, the power of perseverance, and the exploration for the ways of the world. Such themes are the global themes and all of them are focusing on the moral education and teaching. From the themes above, it can be seen that the folktales prior to teach the kindness to the next generation of their society rather than prior to the elements of literature, such as conflict, chracterization, and plot.

Discussing about the various stories according to the traditional and cultural realm in Indonesia, there are two kinds of the most popular folktales, myth and legend. Both of them are almost similar on account of their content of story about the gods and goddess or the human who has the great power like gods and goddess. Lynch Brown and Tomlison (1999) define Myth as stories that recount and explain the origin of the world and the phenomena of the nature (p.99). Then, characters in the myth are gods and goddess and the setting of the story is the imaginary world, because it is originated from the ancient religious rituals. Each societies with their own culture has their own myth with their own characteristics and belief. While in the legend, the characters are the ordinary people who has the gods or goddess characteristics, they have the miracle and power like the gods and goddess. Legend is based on either real or supposedly real individual and their marveleous deeds (p.99). It is the combination between Realism and fantasy.

Medusa, Narcissus, and Apollo are the story about the myth, meanwhile Asterix and Obelix, Hercules, King Arthur, and Sangkuriang are the legend. Usually the myth, like as mentioned above are originated from Greek, Roman, Norse and India values, while the legend usually is originated from the local genious from each own society where such stories are developed. Thus, the legend reflects the characteristics of the culture from a certain society.In line with function of myth, Barthes states that myth has in fact a double function: it points out and it notifies, it makes us understand something and it imposes it on us (p.117). Such statement indicates that the myth actually uses as the media to teach the moral and religious values to the people from one generation to the next generation.

Madura is the island with thousands of folktales as its historical and cultural heritage. The folktales including myth and legend are created the characteristics of Madura people. They are parts of long history which cannot be separated from the society, because folktales are the local genious, a kind of way of thought. Barthes (1973) argues that the very principle of myth, in this sense, is that 'it transforms history into nature' (p. 129). Madura with its all uniqueness transforms its values through the its local genious, like folktales from one generation to the next generation. Surely, inside of the folktales it can be found the moral and religious elements as its standard of philosophy for its people.

Morality, although it can be sourced from a lot of values, but it has the universal standard. From other part of the world to Madura, it has the same standard, because every beliefs and religion has been given its guideline. When the people look at the accident in the street as an example, they will rush in a hurry to help the victims. Such a kind of moral standard and it is not only happened in one part of country, but it will be happened in others. Moral (Dow) itself is defined as the fundamental human behavior that ensures the sustainability, enjoyment and fulfillment of the meaning of life (p.627). Historically, Madura is much influenced by Hinduism and Islam. Both of religions 
affect the development of social and culture in Madura. Consequently, the folktales in Madura are mostly as the reflection of the moral and religious teaching based on both of religions.

Bangsacara and Ragapadmi, Aryo Menak, The Origin of Madura, and Joko Tole are several Madura folktales which are much influenced by Majapahit kingdom. It means that Hindu give much influence to these folktales. While, Aer Mata Ebu is the folktale based on muslim tradition. Such folktales above both of sourced from Hindu or Islam tradition are the reflection of the values in Madura and universally are teaching the kindness. These folktales are very popular in Madura and retold from generation to next generation. The stories are the effective way to teach the moral and give awareness of the religiousness to the children.

\subsection{Research Problem}

The problem of lost the identity as one nation and the confusing to determine how to form the new identity without left the local genious values will be becoming the essential problem today. Thus the exploration of local genious, like through the folktales is needed. Through such phenomena, this paper is aimed to search an appropriate formulation that is related with

1. How religious and moral values reflected in five Madura folktales?

2. How is the religious and moral values in Madura folktales internalized Madurese today?

\subsection{Objective}

Generally, the aim of this research is to find out and get an understanding on how Madura Folktales plays significant roles to identify the religious and moral values from multicultural perspectives.

\subsection{Significance}

This research will contribute to document the Madura Folktales as the heritage of Madura culture as well as to maintain the local genious in Madura. This research is also useful for Madurese to get their identity through the analysis of religious and moral values in these folktales. In education, this research will give an awareness to the learners that Madura has special folktales as a part of their culture which make them different from other tribes.

\subsection{Methodology}

Descriptive - qualitative is used in this research. Qualitative method is appropriate approach because this method can investigate the research questions. It is carried out by the description and interpretation toward the hidden message of folktales and the poems. While the source of data are five Madura folktales. These folktales are chosen because they have close relationship with multicultural perspectives and unique due to its different background of culture in Madura.

\section{DISCUSSION}

The discussion will focus to explore the elements of moral and religious values in five Madura folktales. The word "religious" here does not refer to one religion only, but it refers to religious values in general, or universal values of the religion. While, in relation with moral, mostly the folktales in Indonesia are used for to convey the moral message from the parents to their children, from the teachers to their students. Such moral values are according to the local wisdom as their basic principles.

\section{1 "Heroines" as The Moral Reflection}

Grenby (2008) argues that some critics have argued that moral tales often present a feminist programme (p.68). It indicates that a lot of folktales telling the theme about woman struggle or at least, woman characters are used as the central figure in the story. The women usually are depicted as an "angel" who has a kind heart, good attitude and behavior, and self - sacrifice for other people interest. As the heroine, the woman will oppose "the evil" and overcome the problem as the central of the story. Sometimes, they will be described as the tough women who can face the difficulties in their life.

In Madura folktales, there are several of women characters using as the main and central figure in the story, because of their role, such as Aer Mata Ebu, The Origin of Madura, and AryoMenak. These three folktales try to give the general understanding related with the woman characteristics in Madura.

\subsubsection{Aer Mata Ebu}

The main character in this story is Syarifah Ambami or well - known as RatoEbu. She is Cakraningrat's lady of consort. Cakraningrat is the 
king in Bangkalan and in the past time, Bangkalan is a part of Mataramin Sultan Agung sultanate. Cakraningrat is the great king and has a divine power, thus Sultan Agung likes him very much and asks for him to come to Mataram. In Mataram, Sultan Agung is married off Cakraningrat with his daughter. In Bangkalan, SyarifahAmbami, as the lady of consort lives alone without her husband who live in Mataram. She is very sad when she knows that her lovely husband marry with Mataram princess. But, she tries to face her life, not only as the wife but also as the lady consort.

Being Cakraningrat is rarely come to Bangkalan kingdom, RatoEbu (SyarifahAmbami) must take care of her people and kingdom. She has the duties to keep her kingdom and the wealth of her people, and as the wife she must keep her honor, and her children. She must guide her children alone without her husband. It is really hard for her. Moreover, her husband wants their sons becoming the king in Bangkalan. To satisfy her husband, she prays to God begging to make her seven descents becoming the king in Bangkalan. One day her husband, Cakraningrat goes home to Bangkalan. He asks about his wife's praying. Unfortunately, he is angry and very disappointed with Syarifah's praying, because he wants all of his descents becoming the king not seven descents, then he leaves his wife and backs to Mataram.

Syarifah is very sad, but she does not want her people know that she is sad. Then, she gives her authority to her son, and she goes to Arosbaya hill. In there, she prays every day and night for her people wealth, the prosperity of her kingdom, successful of her sons, and the triumph of her husband. She prays till she tears every day, she sacrifices her life for the glorious of others until she is passed away. Therefore, her attitude and behavior as the wife, the lady consort, and mother is the reflection of morality that is sourced from local wisdom and the traditional values. Her patience faces her husband reflects her high level of morality. She thinks the greater and bigger interest and does not think her personal interest. If she asks to divorce to her husband, what's happened with her sons? her kingdom? her people? Thus, she keeps her relationship with her husband, because she wants the triumphant for her kingdom and the wealth of her people.

Her morality is also the guidance of Madurese women, or at least it can use as the reference how to response while there is a problem in their life.Syarifah in her loneliness attempts to defend her family honor, she is really the kind mother, the tough wife, and the wise lady consort. When she involves the family conflict with her husband, she is not revenge her husband attitude, but she avoids the conflict and alienates herself to Arosbaya hill. Her alienation in Arosbaya hill is the proof that she respects her husband. In her belief, the wife must respect her husband, and she wants her husband aware about it. She spends her life in Arosbaya hill becomes sufism, devoting her life to pray and serving for God. She loves her husband, family, and people very much, so that she sacrifices her life for all of people around her. To commemorate her services, after she is passed away, she is buried in the top of the Arosbaya hill. The position of her tomb in the top of the hill indicates and symbolizes her achievement in her morality and religiousness. She has got the highest level in line with moral and religious standardization.

\subsubsection{The Origin of Madura}

This folktale has the different perspective with Aer Mata Ebu, although it uses mother as the central figure of the story. But, it also has several similarities with the previous story above. In this story, the figure "mother" is depicted as the woman without husband, she never marries with anyone, but because of the gods' miracle, she can be pregnant. She is princess Bendoro Gung, because of her pregnancy, her father, the king of Medang Kingdom, Sang Hyang Tunggal, is very ashamed. Then, he expels her daughter from the kingdom. Not only chasing away her from the kingdom but also her father sending vice regent (patih), Pranggulang kills her while she is in the jungle. But, there is a great wonder due to no weapon can touch her. Pranggulang or KyaiPoleng (vice regent's other name) tries to kill for many times, but he cannot kill her. The next, he is aware that the princess really protected by the gods. Then, he decides to bring her in mount Geger and stay in there till she sends her baby. She gives name her baby, 
Raden Sagoro. Briefly, Sagoro becomes the great warrior, with his high skill in the battle.

When Raden Sagoro grows as the teenager, Medang's soldiers come to Raden Sagoro's place, and asks for help because Meedang kingdom is attacked by another kingdom and got lost. Raden Sagoro asks the permittion to his mother to go, Bendoro Gung who know Medang Kingdom is under controlled her father is allowed her son to go and help Medang's kingdom. In the Battle, Raden Sagoro can beat all of his enemies and get the triumpht. Thus, the king awards him as Minister, but he refuses and tells that he wants back to her mother place and live with her. Finally, The king asks him who is her mother, and the secret is disclosed. The King, Sang Hyang Tunggal cries and begs to apology to sagoro and her mother. Sagoro forgives him, but he doses not want to live in the kingdom. He backs to the wide and dry land where he lives with his mother, Bendoro Gung and his uncle,Kyai Poleng. The wide and dry land, called oro - oro, in the future it becomes Medhuro, or Madura island.

This story is performed, Bendoro Gung as the single parent with her firmness try to keep her only son, Raden Sagoro, after she is expelled from her father kingdom, Medang. She is the great mother due to her patience and toughness she makes her son, Raden Sagoro growing to be the great warrior. As the woman and mother she must faces a lot of difficulties such as the place where they live, it is only dry land and lack of water, many wild animals, and they are isolated because there is no other people except them. She is the kind woman and daughter while she allows her son, Raden Sagoro leaves home to help her father, King of Medang. Although she can forbide her son to go. She reminds her father's attitude who will kill her because of her pregnancy, but she does not want to revenge her father's behavior. On the other hand, she even replies her father bad attitude in the past with her kindness. Bendoro Gung as the central figure in this story is also the pride woman. She forgives her father, Sang Hyang Tunggal. She still appreciates her father however he tries to kill her in the past time. she refuses to back to the palace. She wants to live in "dry land" with her son and she wants develop this land becoming the wealth land in the future.

\subsubsection{Aryo Menak}

In Aryo Menak, the woman character is an angel. She comes to the world together with her six friends. While they take a bath in the beautiful lake, one of the young boy, called Aryo Menak comes and takes one of angel's shawl. This shawl is very important due to without it, the angels cannot back to the paradise. After taking a bath all of angels fly to back the paradise, except one angel who lose her shawl. She cries and Aryo Menak comes. He invites an angel coming and staying with him in his house. The next, Aryo Menak marries her and the new family live happily. They also have a son. But, Aryo Menak has curiousity to his wife, because his rice in the barn is never reduced. He forgets that her wife is an angel who can make a miracle. Actually, his wife can cook with a single rice only, but no one can see it, including her husband, Aryo Menak.

But, one day Aryo Menak breaks his oath, he peeps at what his wife do in the kitchen. At that moment, his wife misses her magic power. She is very disappointed with her husband. But, she tries to continue her life with Aryo Menak. Then, in Aryo Menak area, there suffers the draught. They can not harvest the rice due to such condition. Thus, the stock of rice in the barn is going low and lower till someday the base of the barn is appeared. When the base of barn is appeared, Menak's wife, the angel surprisingly sees her shawl. She is aware that her husband has hide her shawl for long time, then she takes her shawl and flies back to the paradise. Aryo Menak regrets his attitude and he lives alone with his son. But, sometimes his wife, an angel comes and visits them. The angel always gives the welfare to AryoMenak and his people around him, in his village. With her magical power, she makes the rice harvest overflow.

The angel is the real heroine on account of her attitude. Although she is an angel, but she can live like an ordinary people. She never shows her magic power to others including her husband. When she knows that her husband has cheated her by hiding her shawl, she forgives him. She is the angel with her golden heart, she never forgets her life with her happy family. She always visits and keeps her family, she also gives welfare to her husband and his society. Only because of her destiny as an angel, she leaves 
the world and backs to paradise. She never hurts to her husband and she never wants to revenge to him. For her the goodness will be more useful and make the world peaceful rather than enmity and revenge.

\subsection{The Toughness of The Hero Leading to Victory}

(Le Guin in Hourihan, 1993, 2005: 8) Heroes are traditionally male and the hero myth inscribes male dominance and the primacy of male enterprises. Such statement shows how the man usually takes a role as the main character in the story and the man character is dominating the center of the figure in the folktales. The phenomena when the man become the hero is created by the culture and society. Because the man culturally is the central figure in the patriarchal society. It is also happened in Madura folktales too. When there are several main characters as the focus of the story or main character, for instance, Joko Tole and Bangsadcara. Both of stories above use the man as the figure, the man who are depicted as the strong, powerful, kind, and tough figure.

\subsubsection{Joko Tole}

$\mathrm{He}$ is one of the knights from Majapahit Kingdom. $\mathrm{He}$ is awarded by the king because of his service to erect the gate of Majapahit. He is also the most loyal knight in Majapahit. Then, to proof his loyalty, the king of Majapahit asks to Joko Tole to marry with his daughter. Unfortunately, though his daughter is beautiful but she is blind. Because he is the loyal soldier, Joko Tole accepts such marriage. She loves his wife very much. After his marriage, he wants to bring his wife to Madura, he will introduce her to his mother, Potre Koneng. In the middle of their journey, they stop for a while because they are tired and thirsty. The next, they find the lake and the ,princess, Joko Tole's wife wash her face using that water. Suddenly, the miracle is happened, the princess can see, she is not blind anymore.

According to the story above, it can be seen that Joko Tole as the man he has the great loyalty, patience, and toughness. He believes the kindness will be the winner. He has proved, while the king tries to prove his loyalty. He accepts the marriage, he also takes care his blind wife well and patiently. With his patience and toughness he tries to cure his wife.
Finally, he gets the miracle, when in the middle of his trip, he finds the fresh water in the lake, and he asks his wife to wash her face. The miracle is given by the gods because he has graduated from the test. He is proud and never underestimated to his wife, although his wife is blind. He is tough man and husband, while he accepts the marriage and never thought his wife weakness.

\subsubsection{Bangsadcara and Ragapadme}

Ragapadme is the lady consort of the King in Sampang kingdom. She is well known trusts him very much. Thus it raises the curiosity for the other soldiers. One day, there is the disaster in Sampang Kingdom, mumps disaster. Because of such disaster, Ragapadme, the lady consort is contagious of the mumps. She misses her beauty, then, the king rejects her and chases away her from the palace. Bangsadcara is ordered to take care Ragapadme. Therefore, he brings Ragapadme to his mother's house. He and his mother gently take care Ragapadme till Ragapadme heals from her sickness, She gains her beauty anymore. Unfortunately, she refuses to back to the palace, because she has fallen in love to Bangsadcara.

When the king hears the news that Ragapadme has fallen in love to Bangsadcara, The king is very angry and he plans to kill both of them. They leaves the kingdom and invite Bangsadcara to hunt together in the jungle. They goes to the jungle, and in the middle of the jungle, kill Bangsadcara and force. Ragapadme to follow them returning to the palace, Ragapadme refuses and runs to Bangsadcara death body, she takes the dagger and gets suicide. Both of are killed, and they bury in that place. Until now the society still keep the tomb. It is the proof of their true love. Bangsadcara as the hero has the lion heart and the toughness, he patiently takes care Ragapadme the lady consort till she heals from her illness. It reflects his good morality, his kindness, and his level of religiousity.

\section{CONCLUSION}

From the study five Madura folktales above, it can be seen that Madura folktales are full of moral and religious values. The reflection of the moral and religious values can explore through the heroes and heroines views. Such moral and religious values can 
transfer from one generation to other generation as the society will not miss their identity.

richness of the local genious, therefore Madura

\section{BIBLIOGRAPHY}

Barry, Peter. 1995. Beginning Theory. Menchester: Menchester University Press.

Berthens, Hans. 2001. Literary Theory The Basics. New York: Routledge.

Eagleton,Terry. 2008. Literary Theory An Introduction. Minneapolis: The University of Minnesota Press.

Gould Mike. 2004. English Writing Workshop. Singapore: Learner Publishing Ltd.

Grenby, M. 2004. Children Literature. Edinburg: Edinburg University Press.

Grilli, Giorgia. 1997. Myth, Symbol, and Meaning. New York: Routledge.

Hakemulder, Jameljan. 2000. The Moral Laboratory. Amsterdam: John Benyamin Publishing.

Harits, Imron Wakhid. 2011. "The Social Position and Typology of Madurese Women in Madura Folktales," in Atavisme. Vol. 14, Desember, page 194-202.

. 2011 "Enhanching Writing Competence through Madura Folktales: A Case Study at Trunojoyo University Madura," in Nobel, Vol. 02, September, page 23-37.

Horihan, Margery. 1997. Deconstructing the Hero. London: Routledge.

Lynch-braun, Carol, Carl M. Tomlinson. 1999. Essential of Children Literature. Boston: Allyn and Bacon.

Meautia, Cut Intan. 2009. "Pengabaian Pengajaran Local Wisdom dalam Pembelajaran Bahasa," in Prosiding Seminar Nasional 1 Universitas Trunojoyo Madura, Juni.

Sudikan, Setya Yuwana. 2001. Metode Penelitian Sastra Lisan. Surabaya: Citra Wacana.

Wolf, Shelby A. 2004. Interpreting Literature with Children. London: Laurence Erl Baum. 